\title{
The Aquatic Woman: Water and the Feminine Divine in Mia Couto's Terra Sonâmbula
}

MAISHA MITCHELL

Independent Scholar

\begin{abstract}
Mia Couto's 1992 novel, Terra Sonâmbula, is known for its use of fantastic realism to convey the horrors of the Mozambican civil war and their effects. The supernatural invades the daily experience of the novel's characters, and these move from the known world into a frequently aqueous and spiritual one. In this essay, I examine Couto's use of water, the supernatural, and the feminine and link these to African religious and cosmological origins. I see Couto's use of the black feminine aqueous divine as an alternate form of national history that gives voice to those who often go unheard in the chaos of war, particularly women and children.
\end{abstract}

Keywords: Mozambique; Spirituality; Women; Violence; Postcolonialism

Mia Couto's first novel, Terra Sonâmbula (1992), examines the traumatic effects that Mozambique's post-independence civil war had on this emerging nation. Couto juxtaposes several opposing themes: life and death; youth and old age; tradition and modernity; the natural world and the spirit world; earth and sea; women and men. In the present essay, I focus on the connections between Couto's representations of African cosmologies and the beliefs that gave rise to them, specifically those that address the role of the feminine aqueous divine.

It is first worth pointing out that water symbolism is prevalent throughout Couto's fictional and poetic work. Phillip Rothwell presents a thorough 
examination of this theme, arguing that "every time Couto mentions the sea, or draws on the symbolism of water, he enters a discourse on the deep that is both a cultural universal, as a store of human mythological and historical experience" (92). Some of the very titles of Couto's works relate to water, including, Mar Me Quer, A Chuva Pasmada, Um Rio Chamado Tempo, Uma Casa Chamada Terra, and the short stories "De Como O Velho Jossias Foi Salvo das Àguas" and "Natural da Àgua." Even in texts that have terrestrial titles, such as, Terra Sonâmbula and Contos de Nascer da Terra, water plays a significant part. ${ }^{1}$ Domingo Sávio Ferreira de Oliveira proposes that in Terra Sonâmbula, "a água é o elemento libertador; o lugar de renascimento, de fuga da guerra, não existindo espaço para um mar de areia, pois nas águas há muita mais a vida do que a morte. Portanto, a esperança provém da água que restitui a vida" (31). Arthur Hughes argues that the sea in this novel is a space "where the idea of reality is undercut by the fantastic," and that it offers "more fluidity and mobility" (120). These accounts of Couto's work all link water with the unconscious, the feminine, and the fantastic.

What is often left out of critical accounts of the aqueous in Couto's work (and Terra Sonâmbula in particular) are the parallels that exist between water and African spirituality. While Rothwell and others have come close to articulating this by crediting water as a place where the feminine and the fantastic meet, I suggest that there is a decidedly religious aspect that underlies the fantastic elements in Couto's work. More specifically, I argue that several of Couto's characters function as representations of religious figures.

Patrick Chabal has cautioned those who endeavor to analyze Terra Sonâmbula, reminding them that it would be overly simplistic to examine the novel from an anthropological perspective - that is, "to question its African quality on the grounds that the ethnography of belief systems and mythology it depicts does not conform to reality" (84). For Chabal, Couto's novel "is not African because his account of the beliefs of the Matimati is accurate but because the book is written as though it were, or more precisely from the notion that such beliefs matter" (84). While I do explore the roots of African deities and their accompanying belief systems, my goal is not to quantify Terra

\footnotetext{
1 In Contos do Nacer da Terra, there are short stories titled, "A Viagem da Cozinheira Lagrimosa," A Última Chuva do Prisioneiro," "Lágrimas para Irmãos Siameses," and "A Casa Marinha."
} 
Sonâmbula's "Africaness." My main concern is to analyze the impact that African religious belief and practice has on the novel and so foster a better understanding of how Couto's characters recount a history of the people who espouse those beliefs as a way of understanding (and acting in) the chaotic world around them.

Throughout Terra Sonâmbula, Couto employs an idiosyncratic form of fantastic realism informed by African beliefs and traditions. Most notable among these is Mami Wata, a body of female water deities worshipped in various forms throughout Africa. Also central to Couto's novel are Iemanjá and Nanã, the ocean, river, and rain goddesses of Afro-Brazilian Candomblé. The characters Farida, Dona Virgínia, and Assma are in fact representations of the divine powers of these aqueous divinities, which operate in the spirit world, the mortal world, and sometimes in the liminal space between the two. These feminine waters serve in Terra Sonâmbula as the ultimate source of knowledge and understanding, and they form the path to national healing in a patriarchal, post-colonial Mozambique.

\section{The Many Forms of Farida}

Kathleen O'Brien Wicker points out that African religious systems stand out for their "adaptability, flexibility, tolerance and openness" (198). She goes on to argue that these characteristics effectively "differentiate African spiritual traditions from Western religions where faith usually involves acceptance of an articulated set of beliefs posited as absolute truths" (198). One sees the connection between water and the divine in both Western and African belief systems. In Western religions, water is principally a symbol through which believers are reminded of their closeness to God or their obligations to Him. For African religions, divinities and water are combined entities; that is, water is not solely God's creation, a matter unto itself without life force. In African religions, it is the divine itself that transmogrifies into the aquatic, making the former one of the most accessible and common parts of life. This brings the spiritual even closer to the human, making water divinities and spirits "arguably the most adaptable, flexible and innovative of all African divinities, since fluidity is of the essence of their being" (O'Brien Wicker 198). 
Mami Wata is a spirit known for her plurality of form. She can appear as a mortal woman, in dreams, as a mermaid, and she even has masculine energy. She has powers to make the barren pregnant, to heal diseases, and to inspire creativity. For example, "wealthy trader women" in African villages who depend on inspiration to make their crafts stand out from others' may seek Mami Wata's benevolence and help (O’Brien Wicker 204). She dwells in lakes, rivers, and the ocean. Mami Wata may be all things to her devotees or simply a means to meet a particular pressing need such as gaining the affections of a love interest or gaining better financial and physical security.

When Farida first appears in Terra Sonâmbula, she too has many forms. She is first a dancing anchor, then she is a woman, and later she is water itself. Her domain is a shipwreck full of material goods; these indicate wealth, and while Couto presents her with an easygoing nature, she is also clearly very powerful in the aqueous spirit world. ${ }^{2}$ After she shares her stories of her mortal experience with Kindzu, she tells him:

Não acreditas nos xipocos? Pois esu sou da família dos xipocos [...]. Agora, não é que acredite neles, nos espíritos. Sei que sou um deles, um espírito que vagueia em desordem por não saber a exacta fronteira que nos separa de vocês, os viventes [...]. Eu já te tinha visto dessse outro lado, mas as tuas linhas eram de àgua, teu rostro era cacimbo. Fui eu que te trouxe, fui eu que te chamei [...]. Eu sabia que vinhas. Te esperava, Kindzu. (90-91)

Couto's juxtaposition of the spirit world with the mortal world is here informed by an overtly Afrocentric view of spirituality. Traditionally, the water goddess "embodies female control over the crossroads between the ordinary and the extraordinary, between spirits and humans, between life and death" (JellBahlsen 48). Given this, Farida is not only the figure of woman as pleasure, comfort, nourishment, and warmth for Kindzu; she is also the link to his divine

\footnotetext{
${ }^{2}$ Women in lakes, boats, bathtubs and oceans is a recurring theme in Couto's stories. In A Varanda do Frangipangi, Nãozinha has magical powers and disappears into a bathtub of water each night. The character Jessumina from Vinte e Zinco is a diviner who submerges herself for seven years into a lake. At the end of the novel, Irene, the protagonist Lourenço's insane aunt, does the same. Mar Me Quer's Dona Luarmina turns out to be Zeca's father's mistress, who had previously fallen into the ocean while accompanying Zeca's father on one of his fishing trips.
} 
destination. It is she who chose him for the task of helping his countrymen, and it is she who will ultimately call him back to the spirit realm when she is ready. However, Farida is never forceful, and her real power lies in the subtleness of her attraction; she persuades Kindzu to find Gaspar, to be her lover, and to fulfill her other wishes, and he enjoys carrying these out.

Mami Wata is also known to attract men to her in the form of mortal women or through an underwater encounter such as when Kindzu has an intimate encounter with the divine. This undersea experience is unique, given that water divinities are commonly understood to take people with them to learn certain philosophical truths or acquire healing skills (O'Brian Wicker 207). When these individuals return to dry land, their fellows often consider them to exist "beyond the purely bodily level" (O'Brian Wicker 207). ${ }^{3}$ It is also believed that during these encounters Mami Wata will place a demand on the person such as sexual abstinence, an altar for her worship, or dietary restrictions in exchange for their release; should the person honor this promise, they will be blessed (O'Brian Wicker 204). Kindzu's visit with Farida closely parallels this experience, as when the latter asks him a favor:

Certa vez ela se chegou grave. Colocou suas mãos nas minhas e deixou um silêncio pousar. Depois, me [Kindzu] pediu:

- Quando saíres daqui quero que vás procurer meu filho. Hei-de levar Gaspar comigo.

—Não posso, Farida. Vou sair daqui e procurar os naparamas. ${ }^{4}$

- Tu nunca vais encontrar esses teus naparamas. Esquece isso.

-Não posso.

-Não vês que essa gente tambêm é filha da guerra? Quando vencerem ficam iguais aos outros. Vão querer dividir as vantagens com os outros. (Couto 103)

\footnotetext{
${ }^{3}$ In Mar Me Quer, Agualberto has a similar experience when he follows Luarmina into the sea after she goes overboard. Although he attempts to save her, he is unable to do so. Upon returning to the surface his eyes change, and he is insane.

${ }^{4}$ Couto describes the naparamas as "guerreiros tradicionais, abençoados pelos feticeiros, que lutavam contra os fazedores da Guerra. [...] Combatiam com lanças, zagaias, arcos. Nenhum tiro lhes incomodava, eles estavam blindados, protegidos contra balas" (Terra sonâmbula 27).
} 
In giving her opinion of the identity of the naparamas, Farida provides Kindzu with valuable insight. Indeed, after his return to land, Kindzu reflects: "Farida me dera um gusto novo de viver [...]. Depois [...] me tornei encontrável, em mi visível" (Couto 113). One of the main problems that Mozambicans faced after their independence from Portugal was political corruption. Considering this, Gaspar (as Farida's son) represents another connection to the divine, one which the country desperately needs rather than soldiers and officials who pretend to keep the peace while wreaking havoc. Just as Farida takes on many appearances, so the men in Mozambique have various façades.

Couto illustrates the strongest show of divine power over man in Farida and Kindzu's scene of lovemaking. Again, Farida's power is one of subtle attraction, as it is Kindzu who is aroused by seeing her bathe; it is only after she realizes this that she invites him closer:

Juntei-me a ela chegadinho, fosse confiar-me un ilegítimo segredo [...]. Um dedo foi entrando no canto da sua boca. Toquei primeiro em seus dentes, depois senti sua saliva. Era uma saliva quente, parecia que não era apenas um dedo mas todo eu inteiro que penetrava numa caverna aquecida. Outro dedo caminhou nos interiores dela, nervoso de contente. Lá fora, o mar esturdilhava, lançando espumas. O vento soprou com mais raiva, as ondas começaram a varrar tudo, sem respeito. Mesmo ali, no guardado de nossa sala, a àgua jorrava [...]. As mãos molhadas de Farida desataram as vestes, os dedos dela parecia eram de àgua [...]. Nos colámos em gestos de afogado. As vagas ondeavam nossos corpos, indo e vindo. Os dois éramos já só um, emergindo como uma ilha num imenso nada. (Couto 106-07)

This love scene is an inversion of conventional male-female sexual experience, in which it is generally the male who "waters" the fruitful female with semen, thus allowing new life to grow. Kindzu notes the joy he feels upon penetrating Farida, yet it is she who completely envelops him in her waters. Farida leaves her mark upon her lover; it is the ocean, an extension of the womb, and not the phallus that spumes and roars rather than remaining passive during sex, and the waves enter them both. The act of coupling with the feminine divine in this 
case represents a complete transformation of man into one of his essential elements. Woman therefore is always present in man, although he may believe that during sex he affirms the opposite.

Couto further illustrates a divine spirituality inherent in sex and repose when Farida insists that she and Kindzu do not sleep together after their lovemaking, given that "quem dorme no colo de outro perde a alma" and "os sonhos não encontram os repectivos donos quando um homem e mulher dormitam entrelaçados" (Couto 108). Sleep is a key factor in the novel that serves as another connection to the divine. It can be likened to coitus in that there is "an exclusion of external stimuli, the giving up of the "life of relationships" and "the abandoning of interest in every purpose except that which serves wish fulfillment" (Ferenczi 74). Therefore, if one is trapped in the pleasures of love and unconsciousness, it is impossible to carry out one's true calling, which in Kindzu's case is to find Gaspar.

\section{The Love of a Grandmother: Dona Virgínia}

Couto's divine representation of Farida does not stop at the seashore. There are other characters in the novel that are spiritual manifestations. For instance, the relationship between Farida, Gaspar and Dona Virgínia is a rather complex one. Dona Virgínia adopts Farida, but it is her husband, Dom Romão, who sires Farida's son Gaspar. Such a situation, where the white dono of a large plantation in Mozambique fathers a son out of wedlock with a black girl, would normally produce tension and strife between the girl and the dona. However, Couto's novel is about a time and a world where, because of the shock of war, "todo o incrível se torna frequente" (Couto 123). It thus follows that there is more to Farida and Dona Virgínia's apparently serendipitous relationship. This reveals itself with more clarity when perceived through a different paradigm, such as Candomblé. Here Nanã "is the aged female goddess of rain, swamp and soil. She is referred to as the grandmother of the orixás, and [...] she is associated with regenerative properties" (Voeks 124). In addition to these characteristics, there are several healing plants associated with Nanã that her devotees can use for anxiety, colds, and ovarian/uterine problems (Voeks 180182). Furthermore, Nanã is said to have given one of her sickly sons, Omolu, to Iemanjá to raise because she could not cure him. Later Iemanjá decides that the 
boy should reconcile with his mother, and she eventually returns him to Naña's terrestrial realm after he has acquired healing knowledge from time spent in studious isolation. Omolu therefore possesses knowledge of land, springs, and ocean waters and how to release and bind disease (Voeks 79-80).

Like Nanã with Omolu, Farida gives up Gaspar to a convent; however, he runs away when she comes to claim him. Broken-hearted, Farida then "[chora] lágrimas de leite" that "descem brancas na pele escura" (Couto 89): aqueous signs of frustrated maternal love as well as the maternal aspect of Iemanjá who is often referred to as the "milk orixá" (Voeks 123). Here the mother loses her child to the grandmother. Although Gaspar initially distances himself from Farida, he is still connected to her through his adopted grandmother Dona Virgínia, just as Omolu is still connected to Nanã through Iemanjá. When she first finds him sickly and near death, Dona Virgínia believes that he would be better off in the spirit world. She and the neighborhood children eventually decide to save him by placing him in a well:

O poço estava seco, devido da ausência das chuvas. Levavamlhe comidas, lhe trocavam os trapos já molhados e fedorentos. Outro qualquer teria esvanecido. Mas Gaspar era constituido, moço de suar e ressoar. Mesmo dentro do húmido poço ele foi ganhado forças, sua pele se rebrilhou. Quando, de noite, lhe tiravam das funduras eel se mantinha calado, dobrado e vincado. Os meninos, olhos cheios, punham nele toda a expectiva. (Couto 175)

Gaspar's quick recovery is an indication of his divinity; he wastes away while on land but thrives when placed in a moist environment. Like Farida, he tells a story to his new acquaintances, and when he finishes, the rainstorm that accompanies him suddenly stops. The peculiarity of Gaspar's story does not end there. Dona Virgínia, like Nanã, is associated with plants (she is known to be particularly fond of her garden), and it there where Gaspar's body is found. Dona Virgínia goes on to tell Gaspar: "tu és meu filho. Teu pai foi o meu falecido homen, tu és quase-quase do meu sangue" (Couto 176). This claiming of Gaspar mirrors Iemanjá's claiming of Omolu in the ocean. Rather than seeing him as the incarnation of her husband's infidelity, she sees the 
connection between her, him and Farida. This parallels yet another version of the lives of the orixás, in that it is said by some adherents of Candomble that Iemanjá and Nanã are the wives of the same husband, Oxalá (Voeks 124). Because Gaspar has lived with both women, he is also a connection between both worlds, as evidenced when Gaspar returns Kindzu to the spirit world at the end of the novel as a consequence of the latter not keeping his word to Farida.

\section{Sibling Rivalry}

Another orixá in Candomblé is Ibeji, the Yoruba word for "twins," which are still seen as divine beings in parts of Nigeria and Benin. Ibeji are associated with wealth, health, and other blessings, particularly for those who treat them well. The Yoruba believe that Kehinde, the elder twin, sends Taiwo the younger "to be the foreigner for him, to find out if the world is a good place" (Hammersley Houlberg 22). Depending on Taiwo's answer, the two may decide to return to the spirit world or Kehinde, being forewarned, may decide to go alone. Should one or both twins die, ere ibeji are made to represent them. These small wood carvings are often adorned with necklaces of cowrie shells (which symbolize wealth), or beads, and they are cared for just as if they were living children. The Ibeji are to be respected at all times as "if one twin dies and the rituals are neglected, the surviving twin may be lured to the spirit world by its mate [...]. While twins can benefit those who honor them, they can with equal alacrity wreak havoc if neglected. For these reasons they are both desired and feared" (Hammersley Houlberg 23).

In the novel, Farida shares an almost identical relationship with her sister Carolinda, who is also Kindzu's lover. However, there are slight differences in the circumstances of Couto's twins. In Nigeria, Laos, and Benin, twins are welcomed, while in the Mozambique of Terra Sonâmbula they are a bad omen. When Farida and Carolinda are born, the people are forbidden to work the land for fear of drought, a sign of spiritual barrenness. Farida is told that her sister Carolinda died as an infant and was buried in a clay pot near a river of running water, but her Aunt Euzinha reveals the truth to her:

- Sua irmã, sabe ela está onde?

-Minha irmã morreu, tia. 
-Mentira! Sua irmã está muito viva, a morte nem lhe arranhou.

Foram sua palavras. Farida sentiu lágrimas nascerem dentro de si mas fechou-lhes caminho com um sorrriso. A tia dizia coisas sem pés na cabeça.

- Onde está seu fio, o colar que foste dada?

Mostrou o fio. Ela segurou-o por um tempo, apertos a pequena estátua estava pendurada nele...

—Essa madeirinha, essa estátua é sua irmã. Não vê está partida ao meio, é só uma metade? A outra metade quem tem é sua irmã, num colar igual desse. (Couto 78)

While Farida at first cries tears of joy upon discovering this lost sibling, later her sleep is disturbed by nightmares concerning Carolinda's clay coffin. It is revealed that her mother did not follow ritual and have Carolinda killed; instead, she gave her daughter to a barren woman to raise. This creates a sense of resentment in Carolinda and the "demónio se vingava de não ter sido ela a menina escolhida para a vida" (Couto 196). The belief that the deceased twin will somehow draw the living one to the spirit world if both twins are not honored is seen in Carolinda's hostile behavior towards her sister, although the novel presents a slightly different version. When Farida comes to Estevão, Carolinda's husband, for help in finding Gaspar, she becomes enraged:

O ciúme crescia com gusto em Carolinda. Tanto que a sua entrega na cama se passou a fazer com incendida paixão. Estêvão se admirava: que se passa consigo mulher? Mas a tal Farida inesperadamente se retirou de Matimati. Emigara para um naufragado barco e ali ficara. Aquilo que era simples ciúme se converteu em ódio. O que lhe dava tanta raiva? Era perder o objecto do ciúme? Ou seria inveja da outra estar a caminho de sair daquele inferno?... Era essa fuga que Carolinda não podia aceitar. Assim ela se deu a conceber uma vingança contra Farida. Incitava Estêvão a tomar medidas contra o barco, inventando perigos na estada de tal mulher num tal barco. (Couto 185) 
Couto's twins are not a simple retelling of the Yoruba tradition, as they do not remain within their prescriptive roles. Carolinda is clearly the "deceased" twin, as her community perceived her to be dead, and her own mother sent her away. Nevertheless, she does not want her sister to join her in the world of spirits but in the mortal world in which she feels condemned to live. Ironically, it is Farida, the "living" twin, who goes to the spirit world - a switching of places that indicates a shared soul. Couto further illustrates this idea through Carolinda's desire for Farida upon seeing her: "Sua beleza tocava profundamente Carolinda e lhe fazia um gusto de ser homem, poder tocar aquele corpo" (Couto 185). Carolinda's desire is not erotic but rather serves as vehicle for spiritual unity; if she can be intimate with Farida, Carolinda can draw her into her world and thus dominate her just as she tried to do with Kindzu. However, Farida is present in Carolinda's mind even when she is far away. She becomes agitated when Kindzu mentions Farida's name and clearly considers her not only to be a sexual rival but a divine one as well. After her first amorous encounter with Kindzu, Carolinda falsely accuses him of tearing up money and throwing it into the sea as an offering to her sister, just as many Candomblé believers offer gifts to Iemanjá. ${ }^{5}$

\section{The Death of Lusotropicalism?}

While Carolinda's lovers appear to offer loyalty in the mortal realm, Dom Romão, as a personification of Lusotropicalism, steals from Farida on many levels. While Gilberto Freyre eulogizes the figure of the colonizer as brave, ingenious and dutiful, Terra Sonâmbula's version is far less flattering, as Dom Romão is cowardly, lustful, and avaricious. While Farida lives with Dom Romão and his wife Dona Virgínia, he repeatedly rapes her, eventually fathering her son Gaspar:

Desistiu de esperar e se ergueu de um salto, espulada, tirando o corpo do alcance das babas do Romão. Surpreso, o português trancou a voz nos dentes, soprando ameaças. Memórias antigas

\footnotetext{
${ }^{5}$ It is a common practice among Imanjá's followers to participate in New Year's ceremonies on the beach. (Voeks 56,81)
} 
da raça lhe avisaram: melhor seria ela se deixar, sem menção nem intenção. O português se homenzarrou, abusando dela toda inteira. Transpirava imensos suores. Romão surgia cada vez mais peganhento, colajoso como um sapo. Aquele sour lhe surgiu como se fosse a prova: aquele homem era um estrangeiro, retirado do seu mundo. Na sua terra ele pouparia suores ao fazer amor. Mas ele estava deslocado como um sapo longe do seu charco. (Couto 85-86)

This scene is the antithesis of the love scene between Farida and Kindzu in several ways. First, Farida has not yet gone to the spirit world and has not come into her aqueous divine powers. It is Dom Romão, not Farida, who is dominant, and as such, he tries to mark her with his semen and sweat in an attempt to control her body. Couto likens Dom Romão's home domain to a puddle and Farida's to the ocean, a possible allusion to the difference between the respective sizes of Portugal and Mozambique or Africa. The puddle is a fresh water home to a toad, while the ocean is a salt water home to a goddess. Couto also offers a further distancing of these characters: while Farida is deified, Dom Romão is bestialized as a toad, an animal conventionally associated with disease and ugliness. Furthermore, Kindzu observes Farida taking a bath on the ship before their first sexual encounter, and Dom Romão similarly spies on Farida in the bath while she lives with him. The difference however, is that with Kindzu she extends an invitation to join (with) her. Dom Romão's abuse of Farida results in Freyrian mestiçagem gone awry, as their son is anything but the result of a happy union of two races who will eventually "establish [himself] firmly in possession of a vast territory and [...] compete with great and numerous peoples in the extension of [his] colonial domain and in the efficiency of [his] colonizing activity" (Freyre 11). Instead of being a perpetuation of an old (colonial) paradigm, Gaspar marks the end of colonialism in Mozambique. He is not groomed to serve as a member of the "buffer class" of biracial people in the former colony; rather, he is first abandoned by his mother, and his father finds out about him only after he returns from the dead to sow seeds of corruption.

Couto critiques Lusotropicalism also through the relationship between Dom Romão and Salima, the biracial Muslim wife of Abdul Remane. This is a 
specific reference to Freyre, as he makes it a point to comment on Portugal's Muslim heritage and the role of "exotic" women found during Portuguese overseas exploration, stating that: "Long contact with the Saracens had left the Portuguese with the idealized figure of the 'enchanted Moorish woman,' a charming type, brown-skinned, black-eyed, enveloped in sexual mysticism, roseate in hue, and always engaged in combing out her hair or bathing in rivers or in the waters of haunted fountains" (Freyre 12). Dom Romão exhibits this same fascination with a dark Muslim woman when he sees Salima: "[U]m homem em tão magra solidão não tem direito ás redondas morenices? As pretas, Deus me proteja. Mas as mulatas, essas quem as concebeu? Não fomos nós portugueses? Pois então temos direito a petiscar essas lascivas carnes. E Salima, caraças, que graça deperdiçada nas mãos desse escarumba!" (Couto 158). Here, Couto constructs Salima as a product of Dom Romão's ancestors; she is his inheritance, so to speak. He further indicates the connection between Dom Romão and the former colonizers in the narration of their love scene:

Salima se despediu das vestes, açucarando as carnes.

—Romão, para sua satisfeição, que devo fazer?

Sempre aquelas muçulmanias, servindo os prazeres do senhor. Nos cumes do acto de amor, ela interrompia: assim, está bem para si? Nessa tarde, Romão se serviu, lambuzeiro, no banco da cozinha, ela sentada sobre suas pernas querendo lhe prestar melhor que sempre. (Couto 159)

Dom Romão and Salima's sexual union may at first appear to be the archetype of Lusotropicalism, in that it presents a harmonious joining of two races. Salima's "happiness" in serving Dom Romão is, so the logic goes, a proper justification for his actions. He also perhaps desires her more than Farida, not only because of her ethnic background but because she seems truly to enjoy having sex with him, a sign of the desire on the part of the colonized to be colonized. Again, it is Dom Romão who is in power during sex, controlling the situation between the two, arriving at her home whenever he wishes, with the promise of taking her away from her town in return for her favors.

As Freyre presents it, Lusotropicalism is not just about mestiçagem but also the ability of the Portuguese to adapt to any harsh climate or geography and by 
extension to any difficult situation that might affect the body. However, Couto debunks this idea in his depiction of Dom Romão's death as a result of his physical union with Salima:

Desnecessitou-se ali, apontando uma árvore, feito um cão [...]. Sabia bem aquele abrir de um açude no deserto! Mas depois, correndo já as águas há tempos incontáveis, ele se começou a preocupar. Queria parar, não conseguia. Litros e litros lhe escapavam, num caudal que jamais ninguém ajuntara [...]. Foi então que a alma se lhe espeto no visto: as cuecas estavam manchadas de vermelho, quase pingavam.

-A puta estava com os sangues, raios a partam! (159-60)

The taboo of menstrual sex here functions on many levels. Dom Romão accuses her of "bewitching" him and demands that she sleep with her husband so that he too may die. This situation serves as a contrast to Dom Romão and Farida's liaison, in that here nothing is brought into the mortal realm from the spiritual. Rather than creating life, as in Gaspar's conception, Dom Romão shares the death of Salima's ovum. Amniotic fluid is associated with Oxum, the Candomblé goddess of fresh waters, and Farida's womb fills with it as Salima sheds her fluids. Dom Romão's death likewise presents African mysticism as a means to end overt Portuguese domination.

\section{Assma's Return}

While the focus of Terra Sonâmbula is Kindzu's journey and relationship with Farida, there is a tertiary character that also represents the link between water and spirituality: Assma, the wife of Kindzu's friend Surrendra. She is the most passive character of the novel, as she hardly speaks or acts beyond listening nostalgically to the Indian programs on the radio in her husband's shop. Nevertheless, there are parallels with other syncretic aspects of Mami Wata:

The Indian strand in the Mami Water métissage probably derived from contacts with Gujarati merchants along the west coast of Africa around the period of the First World War. Indians set up 
successful commercial enterprises which brought them to the notice of Africans who [...] then appropriated elements of Hindu praxis into their rituals in honor of Mami Wata. (O'Brien Wicker 202)

Assma is something like the peaceful, ideal result of this métissage; an Indian living in Mozambique who is familiar with Portuguese culture, she is a living hybrid, as is her husband Surrendra Valá. As Surrendra pushes Assma off in a raft, he orders her to return to India: "Vai Assma! Volta na sua terra!" (Couto 126). Drawn from her sea voyage by a greedy fisherman, Assma lies beautifully yet sickly on the beach, a living piscine attraction for which people pay to see. However, her hair has grown longer and her skin lighter, indicative of a possible underwater transformation commonly associated with Mami Wata. Upon leaving the divine space of the ocean, Assma instantly becomes not an object of worship, but is exploited just as Farida was in the mortal realm. Later on, she is burned alive by angry Mozambican blacks who reject the presence of Indians in the country. Assma and Farida indicate two paths that the country can take: either Mozambicans can focus on the differences that divide them and thus continue down a path of destruction or they can choose to focus on what joins them and use that as a basis for nation building.

Surrendra and Kindzu make the connections between water, divinity, and peace. Kindzu and Surrendra both attribute their mutual affection to the fact that they as a coastal people, linked to the Indian Ocean:

Nós, os da costa, éramos habitantes não de um continente, mas de um oceano. Eu e Surendra partilhávamos a mesma pátria: o Índico. E era como se naquele imenso mar se desenrolassem os fios da história, novelos antigos onde nossos sangues se haviam misturado. Eis a razão por que demorávamos na adoração do mar: estavam ali nossos comuns antepassados, flutuando sem fronteiras. Essa era a raiz daquela paixão de me encaseirar no estabelecimento de Surendra Valá.

—Somos da igual raça, Kindzu: somos índicos! (Couto 26) 
This shared sensation is representative of the "thalassal regressive trend" described by Sandor Ferenczi as the "striving towards the aquatic mode of existence abandoned in primeval times" (52). The ocean is a place Mozambique's vanished harmony, which makes it all the more desirable. Assma and Farida become for Surrendra and Kindzu the incarnation of a peace they desperately want despite others' inability to see it. There is a dichotomy that exists between the four elements. The masculine elements, earth and fire, are connected in the novel to destruction and war as there are male soldiers who use arms to exert power. The feminine elements, water and air, are again connected to the divine and healing. As Surrendra and Kindzu represent males who recognize and revere water, they are caught in a liminal space between opposing sides. The difference, however, is that Surrendra becomes a sleepwalking victim of the terrestrial warfare, while Kinzdu tries to stop it.

\section{Conclusion}

In Terra Sonâmbula, civil war takes its fill of the dead and leaves the living between the earthly and spiritual realms, making goddesses and gods of servant girls, dutiful wives, and orphans. This contradiction-mortal divinitysymbolizes the intrinsic potential in humankind to destroy and rebuild itself if it so chooses. Couto's oceans and rivers are a place of healing, mystery, death, resurrection, succor, and energizing spiritual forces that serve as escapes from terrestrial horrors. Oceans and rivers magically dry up and reappear in the novel. Human potential for good operates in a similar manner; it is ever-present but not always employed. As agents of the aqueous divine, Farida, Gaspar, and Dona Virgínia represent the healing aspects that can be activated within people when faced with the tragedies that wars bring. This does not mean that justice is always accessible for those who have been wronged in conflicts but rather that new beginnings are possible even amid chaos.

\section{Works Cited}

Banks, Jared. "Mia Couto." Postcolonial African Writers: A Biobibliographical Critical Source Book, edited by Pushpa Naidu Parekh and Siga Fatima Jagne, Greenwood Press, 1998, pp. 111-17. 
Chabal, Patrick. "Mozambique." The Postcolonial Literature of Lusophone Africa, edited by Patrick Chabal, et al., Northwestern UP, 1996, pp. 84.

Couto, Mia. A Veranda do Frangipangi. Caminho, 1996.

-. Contos do Nascer da Terra. Caminho, 1997.

- Mar Me Quer. Caminho, 2000.

- Terra Sonâmbula. Caminho, 1992.

- Vinte e Zinco. Caminho, 1999.

Ferenczi, Sandor. Thalassa: A Theory of Gentiality. Norton, 1968.

Freyre, Gilberto. The Masters and the Slaves, translated by Samuel Putnam, Knopf, 1946.

Hammersley Houlberg, Marilyn. "Ibeji Images of the Yoruba." African Arts, vol. 7, no.1, Autumn, 1973, pp. 20-27.

Hughes, Arthur. "Shifting Landscapes, Spatiality, and Unstable Identity: Mia Couto's Terra Sonâmbula." In and Out of Africa, edited by Joana Boampang, Cambridge UP, 2012, pp. 119-35.

Jell-Bahlasen, Sabine. "The Lake Goddess Uhammiri/Ogbuide: The Female Side of the Universe in Igbo Cosmology." African Spirituality: Forms Meanings and Expressions, edited by Jacob K. Olopuna, Crossroad, 2000, pp. 38-53.

O'Brien Wicker, Kathleen. "Mami Water in African Religion." African Spirituality: Forms, Meanings, and Expressions, edited by Jacob K. Olopuna, Crossroad, 2000, pp. 198-222.

Oliveira, Domingo Sávio Ferreira de. "O Chão e a Água em Terra Sonâmbula: Realidade e Ficcão, Oralidade e Humanização Fantasiosa," Revista de Estudos de Literatura, Cultura e Alteridade-Igarapé, vol. 4. no. 1, 2014, pp. 26-37.

Rothwell, Phillip. A Post-Modern Nationalist: Truth, Orality and Gender in the Work of Mia Couto. Bucknell UP, 2004.

Voeks, Robert A. Sacred Leaves of Candomblé. U of Texas P, 1997.

Wafer, Jim. The Taste of Blood: Spirit Possesesion in Brazilian Candomblé. U of Pennsylvania P, 1991. 